DOI https://doi.org/10.30525/978-9934-26-173-2-49

\title{
EMPLOYING THE MATERIALS OF THE MUSEUMS OF THE WORLD FOR MASTERING VOCATIONAL VOCABULARY BY THE STUDENTS OF THE FACULTY OF THEORY AND HISTORY OF ART
}

\author{
Smolianinova S. V., Mkhitarian L. S. \\ Senior Lecturers of the Foreign Languages Subdepartment \\ National Academy of Fine Arts and Architecture \\ Kyiv, Ukraine
}

According to the requirements of «National ESP Curriculum for Universities», teaching foreign languages in non-linguistic Universities has to be vocational. Vocational vocabulary differs for every specialization significantly. Thus, the methods of teaching, grounded on the same generalized methodology, must be conditioned by a certain specialization. This research is dedicated to the development of the range of practical tasks and methods for the students of the Faculty of Theory and History of Art and also gives their theoretical analysis aimed at improving the quality of teaching and the effectiveness of mastering vocational vocabulary. The main target is to improve the methodology of teaching vocational English for the students of the Faculty of Theory and History of Art of NAOMA and diversify it.

The lecturers of the Department of Foreign Languages of NAOMA developed the range of scientific and methodological works for teaching vocational vocabulary to students of various faculties of NAOMA. These are the book «English for Art Students» by the Head of the Department Oleksandr Yudenko and the book for the Art students, who are doing Master degree course, «Let's talk Art» by Liudmyla Mkhitarian and Tetiana Kresan, where one can find wide range of authentic texts on Art History and exercises for practicing vocabulary.

Vocational vocabulary for Art History students is the range of vocabulary, semantically connected with Art in general, vocabulary, which refers to the Theory and History of Art or which is employed in analyzing the works of Art and Art objects. Furthermore, involving culture is one of the essential aspects of teaching foreign language the Art History students. A science, studying this, is named Linguoculturology. It has been separated recently and it is grounded on the linguistics and culturology.

Studying foreign language just by using the books will lead to the fact that the students' knowledge will differ from the real situation in the world of art. In addition, most students who currently study at the faculty of Theory and 
History of Art, work part time at various galleries and museums, and therefore understand inconsistency of the language, taken only from the texts in their books with real situation, which they must be able to deal in practical life. For this reason, the essential task of the teacher, who works in Higher Educational Establishment, is to create a lesson, where linguoculturological principals will be realized and implemented into practical studying situation, aiming at the same time at achieving high vocational level of foreign language at the students.

The main structural unit of teaching language is a word. Therefore, to incorporate museum artworks to the lessons of foreign language we suggest working directly with museum labelling, which is compulsory compliment of every work of art, kept in a museum. The advantages of this are the following: They are always introduced by two languages - English, and Native language. As we consider prominent world museums, English translation is advanced and does not contain mistakes, as it might happen on the Internet or in certain books, written by non-native speakers. Nowadays it is relatively easy to find the depictions of paintings and information, introducing them, in the internet. However, thorough research on the topic revealed, that most prestigious European museums and galleries observe privacy carefully, allowing the free access to only a particular part of information concerning their rare and unique exhibits. The information, given in the internet and in books, still can not replace what one can find out in a real museum, where all exhibits, from paintings to archaeological findings, belong to the world of art.

A painting label in a museum might be shortened, but in most cases, it is introduced by a large-scale text, which corresponds an advanced level in classification of teaching foreign language (C1-2). The vocabulary is usually rich on synonyms, topical for art critics and grammar consists of quite complicated and important structural units. The texts of such level correspond the contemporary requirements and vocational principle of studying. Due to the fact, that this is topical, working with labels can even replace working with the texts from the books. Such activity at the lessons of Foreign Language increases motivation, which is one of the main purposes of teaching methodology.

Such work leads to realisation of the cognitive-communicative approach in British methodology, integrated into original British books for teaching English of such respectable Publisher houses as «Oxford University Press», «Pearson Longman», «Cambridge University Press». In our particular case for university students- art critics, whose language level is high and who are experts in the field of art, we suggest activity, named «extending initial information». Thus, students receive the task of recalling all possible additional information, connected with a biography and works of the artist, 
their particular artistic approach and report to the class. The main difference from brainstorming is that while brainstorming students collect creative ideas for solving the problem. Here, the students collect additional information on the topic, report and exchange it. Due to this, every person in class has an opportunity to make their own contribution into the lesson, which favors raising the students' self-awareness. Every new piece of information generates association memory and triggers recalling further information on the topic, which leads to revealing new valuable facts. Personal research of such lessons shows that the next step of such activity is discussion in the form of friendly conversation or even an argument, as other students might disagree with the information, known by only one person before. This way, involving students into arguing and making attempts to prove their point of view, while speaking the language which they study, a teacher is able to realize in practice cognitive criteria of conscious learning and to develop skills of spontaneous speaking on vocational topics, which is the vital aim of teaching university students. The principles of interactivity and collective thinking are followed. The atmosphere of friendliness and creativity is prevailing at the lesson. The process of communication is natural. Critical thinking is being developed, which broadens the mind, improves imagination and clarity in perception the information.

Another important part of the exercises develops namely vocational vocabulary and works with a word as a lexical unit. In our opinion, in case the students' language level is quite high, it is not recommended to translate the text into native language. This way it becomes possible to imitate linguistic environment during the lesson. The first thing which should be done to work with a semantical meaning of a lexical unit is explaining the meaning of one word or phrase in foreign language using synonyms or students' own ideas or giving its definition. Secondly, exercises for practicing synonyms should be done. Thirdly, we analyze the proximity of the synonyms in their meaning and elicit stylistic differences between them, selecting neutral lexical units and trying to find corresponding synonyms in colloquial, formal or literary styles.

Another activity has a target audience and aimed at the students of artistic university. It is essential skill for an art critic to learn to describe and analyze a work of art, which is a focal point of their studying. Most part of the curriculum program in art critic faculty is dedicated to a painting analysis. So, the main task of a foreign language lesson while teaching the vocational vocabulary is to teach the students to analyze paintings in foreign language as well as in their native language. We suggest that at the lesson students should be shown a photograph of a label with a text but without a photograph of a painting. Students should be put in pairs. Their task is to imagine a painting itself by its description. After that one person in pair describes it to their 
partner, practicing speaking skills and using a vocabulary of the lesson. At this time a partner is trying to depict what is being described, developing their listening skills. This activity leads to a significant result, as it involves several types of memory, such as motor memory - while depicting what is being described, imagery memory - imagination and visual thinking is being developed, emotional memory, as emotions are integral part of this exercise, which increases memorizing.

Since museum jobs constitute a significant part of employment for the graduates of the faculty of Theory and History of Art, it is vital to employ labelling into teaching English to future art critics. Due to such practice, a museum worker will have clear understanding of vocabulary, which they will be going to work with, and will be able to correct mistakes in labels and other information concerning museum exhibits. This will also increase the level of their education and will help to achieve efficient result in learning vocational vocabulary at the lessons of foreign language, minimizing a gap between a lesson and real life, integrating English into sphere of students' interests.

\section{References:}

1. Бакаєва Г. С. Борисенко О. А. Зуєнко I. I. National ESP Curriculum for Universities. Програма 3 англійської мови для професійного спілкування. Київ: Ленвіт, 2005.

2. Кравець Л. В. Лінгвокультурологія // Енциклопедія Сучасної України: електронна версія [веб-сайт] : https://esu.com.ua/search_ articles.php?id=5550921 вересня, 2021

3. гол. редкол.: І.М. Дзюба, А.І. Жуковський, М.Г. Железняк та ін.; НАН України, НТШ. Київ: Інститут енциклопедичних досліджень НАН України, 2016. с.138.

4. Матеріали Всеукраїнської науково-практичної конференції, 6-7 Квіт. 2012 р. У 3 томах, Дніпропетровськ, 2012. Том 2, с. 23-25.

5. Мхітар'ян Л.С. Кресан Т.Д. Поговоримо про мистецтво. Методичні рекомендації для студентів художніх спеціальностей. Київ: HАОМА. 2019.

6. Юденко О.І. Англійська мова для студентів та аспірантів вищих мистецьких навчальних закладів. Київ: Фенікс, 2008. 